\title{
PEMANFAATAN E-COMMERCE DALAM PENINGKATAN PENJUALAN PADA BURGER SEI PUTIH KOTA MEDAN
}

\author{
T. Alvi Syahri Mahzura \\ Fakultas Ekonomi dan Bisnis, Universitas Medan Area \\ zuraxzaid@gmail.com
}

\begin{abstract}
The purpose of this study is to determine the benefits of e-commerce in increasing sales of the Sei Putih Burger in Medan. Proxied e-commerce is a social media platform such as Instagram and blogs as well as marketplaces such as Grab food and Go food. The research method is descriptive qualitative, which describes respondents' answers and interview results which are then presented in tables and graphs using primary data sources and data collection techniques in the form of interviews, distributing questionnaires and observations. The results obtained show that the use of e-commerce in increasing sales is an increase in profits, increased partner relations, is known to the wider community, a better internal control system and better financial management ability to invest in assets such as gold and land. However, on the other hand there is a negative impact from the use of E-commerce in increasing sales, namely the cancellation of orders from customers, unavailability of large parking lots, network constraints on EDC machines and fictitious order opportunities.
\end{abstract}

Keywords: E- commerce, Marketplace, Penjualan

\section{PENDAHULUAN}

\section{Latar Belakang}

Kehadiran sebuah UMKM (Usaha Mikro Kecil Menengah) di Negara Indonesia berperan penting menekan angka pengangguran, menyediakan lapangan kerja, mengurangi angka kemiskinan, meningkatkan kesejahteraan dan membangun karakterbangsa. Aspek - aspek tersebut didapat melalui aktivitas kewirausahaan. Persaingan membuat UMKM harus mampu menghadapi tantangan global,seperti meningkatkan inovasi produk dan jasa, pengembangan sumber dayamanusia dan teknologi, serta perluasan area pemasaran. Hal ini perlu dilakukanuntuk menambah nilai jual UMKM, utamanya agar dapat bersaing denganproduk - produk asing yang kian membanjiri sentra industri dan manufaktur diIndonesia, mengingat UMKM adalah sektor ekonomi yang mampu menyeraptenaga kerja terbesar di Indonesia (Sudaryanto, 2011) dalam(Setyanto et al., 2015). Tantangan dalam dunia bisnis zaman sekarang adalah harus 
bertransformasi dalam memasarkan produknya melalui media digital yang memerlukan pengetahuan teknologi bagi sumber daya manusia yang menjalankan bisnis tersebut.

Menurut (Ngafifi, 2014) perkembangan dunia ilmu pengetahuan dan teknologi (IPTEK) yang demikian mengagumkan tersebut memang telah membawa manfaat yang luarbiasa bagi kemajuan peradaban umat manusia. Jenis-jenis pekerjaan yangsebelumnya menuntut kemampuan fisik yang cukup besar, kini relatif sudah bisa digantikan oleh perangkat mesin-mesin otomatis.Karena UMKM sangat menunjang pertumbuhan ekonomi negara maka untuk mencapai target penjualan adalah harus mengadaptasi metode pemasaran bisnis secara konvensional menjadi pemasaran online yang banyak menghemat biaya operasional dan berdampak pada laba bersih.Mengikuti perkembangan Revolusi Industri 4.0 yang berhubungan dengan dunia teknologi, saat ini masih menjadi sebuah kendala bagiUMKM di Kota Medan yaitu adaptasi pengetahuan teknologi dengan cara masuk ke dalam dunia pemasaran online (Electronic-commerce) dengan tujuan meningkatkan produksi penjualan dan perekonomian.

Menurut (Pradana, 2015b)e-commerce merupakan suatu inovasi dalam dunia wirausaha, pengembangan model ini didasarkan atas jaringan atau internet. Semakin meningkatnya pengakses internet di dunia ini diharapkan menjadi hal yang dapat menarik perhatian para pelaku bisnis dalam mengembangkan usaha.Beberapa penelitian mengenai pemanfaatan e-commerce membantu meningkatkan volume penjualan usaha maupun bisnis telah dilakukan diantaranya penelitian yang dilakukan oleh (Alfandia, 2019), (Pradiani, 2018), (Rakanita, 2019), (Suprapto, 2016) dan (Siska Maya, 2016). Hasil yang berbeda dari penelitian (Wiyani \& Nugroho, 2013) bahwa terbatasnya sumberdaya manusia yang terampil memanfaatkan Teknologi Informasi (TI) dalam hal ini menerapkan e-commerce untuk pemasaran produknya. Namun demikian mereka mempunyai motivasi yang tinggi untuk mencari pelanggan baru dan meningkatkan pendapatan. Hal ini terjadi pada salah satu UMKM di Kota Medan yaitu Burger Sei Putih yang berdiri pada tanggal 30 November 1989 dan berhasil bertahan sampai saat ini walaupun semakin banyak pesaing baru dengan jenis produk yang sama yaitu Burger. Burger Sei Putih Kota Medan memiliki daya tarik kaum muda dari tahun 1989 sampai saat ini karena memiliki harga Burger yang ekonomis di kantong masyarakat.

Meskipun kuantitas setiap hari banyak terjual, namun pemilik memiliki masalah yaitu belum dapat mengendalikan sistem keuangan dengan baik karena masih menjalankan sistem pembukuan manual berdasarkan kepercayaan pada karyawan dalam mencatat transaksi setiap hari tanpa diawasi satu hari penuh. Ketiadaan pengawasan keuangan membuat pemilik kesulitan untuk mencadangkan kelebihan dana untuk investasi asset. Kesulitan yang dihadapi pemilik usaha ini 
membuat pemilik tertarik ingin bermitra ke pemasaran produk secaraonline dengan tujuan segala transaksi keuangan atau sistem pembayaran yang dilakukan konsumen adalah non - tunai (cashless) dan akan langsung masuk ke dalam rekening pemilik, sehingga dapat meminimalisir celah fraud (kecurangan) yang bisa dilakukan oleh karyawan. Ini adalah upaya transformasi yang dilakukan oleh pemilik dan dengan kemampuan pengetahuan teknologi yang dimiliki oleh para karyawan yang bekerja maka penerapan e-commerce dalam meningkatkan penjualan akan sangat membantu. Tujuan dari transformasi tersebut adalah pemilik ingin memperbaiki sistem pengendalian internal usaha dan sistem manajemen keuangan karena memiliki tujuan dapat melakukan investasi asset seperti emas dan tanah secara tunai dan tidak memilih jalur perkreditan di perbankan karena menghindari riba.

\section{KAJIAN LITERATUR}

\section{E-commerce}

Terdapat beberapa pendapat mengenai definisi dari E-commerceatau Electronic commerce yaitu merupakan sistem pemasaran denganmenggunakan aksen jaringan internet baik dilakukanmelalui situs web, aplikasi mobile atau browser padaperangkat mobile atau komputer yang digunakanuntuk melakukan transaksi bisnis, salah satunyatransaksi komersial antar organisasi atau antarindividual.E-commerce ini mempunyai ruang lingkup yang mencakuplayanan distribusi, marketing, jual beli, layananpurna jual dan service produk yang secarakeseluruhan dilakukan pada sistem elektronikaseperti jaringan internet. E-commerce dapat puladiartikan sebagai perpaduan jasa dan barangdengan kegiatan transaksinya dilakukan melaluijaringan internet, dengan harapan dapat menjadiroda penggerak dalam memperbaiki ekonomidomestik dan mempercepat terintegrasinya kegiatanproduksi global (Fitriyadi, 2019).

(Pradana, 2015a)mengemukakan e-commerce adalah sebagai suatu upgrade atau pembaharuan dalam dunia wirausaha di mana semua kegaiatan bisnis atau usaha dilakukan dengan tanpa kertas atau paperless yang berbasis jaringan.Electronic commerce merupakan salah satu teknologi yang berkembang sangat cepat dan semakin banyak pengakses internet di seluruh dunia. Pengguna smartphone telah berkembang pesat dan sekaligus menjadi kebutuhan utama saat ini. Hal ini menyebabkan seluruh tingkat usia dapat terlibat dalam transaksi e-commerce selama mereka memiliki akses jaringan internet.Tidak hanya perusahaan besar yang menerapkan penjualan bisnisnya melalui e-commerce namun banyak UMKM juga telah menerapkan sistem pemasaran secara online dalam rangka meningkatkan daya saing dan volume penjualan. Hal ini dibuktikan 
dengan penelitian yang dilakukan oleh (Rakanita, 2019)dan (Suprapto, 2016)bahwa pemanfaatan $e$ commerce dapat meningkatkan penjualanproduk.

\section{Marketplace}

Menurut Brunn, Jensen, \& Skovgaard (2002), e-marketplace adalah wadah komunitas bisnis interaktif secara elektronik yang menyediakan pasar dimana perusahaan dapat ambil andil dalam B2B e-commercedan atau kegiatan e-business lain (Agusalim, 2020)

Terdapat dua jenis e-marketplaces:

1. e-marketplaces horisontal dikategorikan berdasarkan fungsi atau produk umum yang ditawarkan perusahaan. Dapat diartikan pasar yang digunakan untuk industri umum. Seperti pasar penjualan, baju. Biaya transaksi yang dikeluarkan lebih rendah.

2. e-marketplaces vertical dapat diartikan pasar yang digunakan untuk industri yang memenuhi kebutuhan khusus pada masing-masing industri. Seperti pasar penjualan beton, baja.

Umumnya masyarakat mengetahui mengenai marketplace yang banyak digunakan pebisnis, namun menurut Awaluddin (2016) dalam (Siska Maya, 2016) adapun hal - hal yang harus diperhatikan ketika mengambil langkah dalam memasarkan produk secara online agar semakin berkembang yaitu:

1. $L O O K$ (Kreatif untuk menarik pengunjung)

Menarik pasar via online butuh strategi tersendiri. Pengguna media sosial seperti twiter, facebook, instagram, path dan linkedin di Indonesia jumlahnya mencapai puluhan juta akun. Hal ini dapat di manfaatkan untuk mengkomunikasikan produk dan menciptakan efek viral marketing dari media tersebut.

2. $B U Y$ (Tawarkan sesuai kebutuhan pasar)

Memerlukan kemampuan untuk menganalisa berdasarkan data yang ada. Penyediaan kemudahan akses untuk pembelian, mulai dari deskripsi produk, spesifikasi dan ukuran produk, ketersediaan produk dan kemudahan pengiriman.

3. $P A Y$ (Sediakan akses pembayaran yang mudah)

Pembayaran menjadi usnsur yang tidak kalah penting. Pembayaran bisa melalui sistem kartu kredit, electronic payment gateway, transfer atau pilihan cash on delivery. Konsumen Indonesia sedang dalam proses menuju e-Payment. 
Jual beli atau perdagangan secara online dapat dilakukan melalui situs jual beli online (marketplace), dalam aplikasi maupun media sosial dengan membuat akun profil produk yang dijual dan disertai testimoni pelanggan untuk menarik perhatian konsumen lain. Media sosial tersebut juga menyediakan tautan yang menghubungkan ke aplikasi percakapan online seperti Whatsapp untuk melanjutkan transaksi jual beli. Masyarakat saat ini dimanjakan oleh fitur-fitur digital seperti ini yang dapat menghemat biaya, waktu dan energi dengan menggunakan jasa aplikasi tersebut.Saat ini beragam jenis bisnis atau usaha menerapkan sistem pemasaran secara online dengan memanfaatkan para penggunainternet. Termasuk adanya $e$-commerce bisnis kuliner melalui Instagram, Blog, Grab Food dan Go Food. Pada masing- masing daerah di Indonesia terdapat Grab Food dan Go Food yaitu media di dalam sebuah aplikasi yang menampilkan menu menu kuliner di wilayah pelangan masing- masing. Kedua aplikasi tersebut tergabung di dalam aplikasi transportasi online masing - masing yaitu Grab dan Gojek. Pelanggan cukup mengunduh aplikasi tersebut, lalu jika ingin memesan makanan ketik nama restoran kemudian pilih menu, setelah itu kurir dari Grab atau Gojek yang akan membeli pesanan pelanggan dan mengantar pesanan tersebut ke pelanggan.

Grab Food dan Go Foodsebagai marketplace kuliner memiliki tujuan yang sama yaitu memasarkan secara online kuliner suatu daerah dengan diantar oleh kurir dari perusahaan masingmasing dengan syarat kemitraan yang berlaku di masing-masing perusahaan. Ketika restoran sudah melakukan kemitraan dengan Grab Food dan Go Food maka ada banyak keutamaan yang didapat oleh restoran seperti menjadi restoran pilihan, pemasaran lebih luas dan dikenal dan keuntungan yang meningkat. Dengan syarat yang dipenuhi oleh pelaku usaha kepada Grab Food dan Go Foodakan diperoleh keuntungan baik bagi Grab Food dan Go Food, pelaku usaha dan driver (kurir).

Sejalan dengan banyak pengakses internettentunya konsumen akan menggunakan salah satu sub jasa transportasi onlinekhususnya kulinertersebut. Inilah penyebab mengapa banyak para pengusaha kuliner memakai jasa $e$-commerce diantaranya Instagram, Blog, Grab Food dan Go Food karena pasarnya sudah ditemukan hanya dengan melalui sistem online. (1) Kuota internet, (2) biaya tenaga kerja seperti administrasi pelayanan online, (3) desain foto menu - menu kuliner dan (4) memberikan produk secara gratis kepada selebgram (tokoh terkenal di sebuah sosial media/instagram) untuk mengiklankan produk tersebut sehingga para pengkases internet tertarik membeli produk karena ulasan dari selebgram tersebut. Kemudahan pemasaran bisnis secara online dari empat poin tersebut membuat banyak pengusaha bisnis kuliner bertransformasi sistem pemasarannya digital. 


\section{Penjualan}

Pengertian penjualan menurut Philip Kotler adalah proses sosial yang di dalamnya terdapat perorangan atau kelompok untuk mendapatkan sesuatu yang mereka butuhkan atau inginkan dengan cara menciptakan, menawarkan dengan secara bebas untuk menukarkan produk yang bernilai dengan pihak lain(Talenta, 2020). Penjualan memiliki pengaruh yang strategis terhadap perusahaan, karena penjualan yang dilakukan oleh perusahaan harus didukung dengan harta atau asset, bila penjualan ditingkatkan maka asset pun harus ditambah (Weston \& Brigham, 1991).

Menurut (Suprapto, 2016) penjualan menjadi suatu kegiatan penghubung antara perusahaan dengan konsumen untuk merealisasikan tujuan terakhir pemasaran. Sumber pendapatan suatu perusahaan adalah berasal dari penjualan, karena dengan adanya penjualan dapat mengubah posisi harta perusahaan. Pertumbuhan penjualan memiliki peranan yang penting dalam manajemen modal kerja(Dewinta \& Setiawan, 2016). Tujuan dari penjualan antara lain:

1. Mendapatkan Volume Penjualan

Setiap perusahaan pasti memiliki tujuan penjualan yang ingin dicapai. Jumlah penjualan perusahaan tentunya diharapkan bisa bertambah setiap bulan atau tahunnya untuk membantu meningkatkan performa usaha.

2. Mendapatkan Laba

Tujuan utama penjualan adalah mendapatkan laba atau keuntungan dari produk yang dijual. Dengan pengelolaan yang baik, perusahaan atau usaha Anda akan mendapatkan laba yang besar dan mendapatkan pelanggan tetap (loyal customers).

3. Menunjang Pertumbuhan Perusahaan

Jika perusahaan mencapai target penjualan yang ditetapkan, tentunya usaha akan cepat berkembang dan mencerminkan ukuran perusahaan. Hal ini juga dibantu dengan peningkatan kinerja dari perusahaan sebagai distributor dalam menjamin kualitas barang yang dijual.

\section{METODE}

Penelitian ini menggunakan penelitian deskriptif kualitatif yaitu menggambarkan bagaimana aktivitas para pelaku usaha atau pebisnis dalam memanfaatkane-commerce dalam meningkatkan penjualan. Analisis data dilakukan secara kualitatif, yaitu dengan mendeskripsikan jawaban responden dan hasil wawancara yang kemudian disajikan dalam bentuk tabel dan grafik. Jenis data primer yang digunakan dalam penelitian ini dengan metode pengumpulan data terdiri dari:

a. Wawancara 
Melakukan wawancara langsung terhadap pemilik usaha dan karyawan yang berhubungan dengan bisnis Burger Sei Putih untuk mendapatkan informasi data penelitian.

b. Kuesioner

Menggunakan kuesioner untuk menggali informasi dari responden yaitu konsumen dan karyawan mengenai Burger Sei Putih

c. Observasi

Melakukan pengamatan langsung pada objek penelitian.

Kuesioner kepada responden melalui Google Forms. Populasi dalam penelitian ini adalah penduduk Kota Medan yang lahir pada tahun 1990 - 2001 yang memanfaatkan aplikasi pembayaran digital (digital payment). Kuesioner yang disebarkan melalui Google Forms pada responden sebanyak 250 unit. Teknik pengambilan sampel yang digunakan dalam penelitian ini menggunakan teknik purposive sampling yaitu teknik untuk menentukan sampel yang dengan sengaja mengambil sampel tertentu sesuai dengan tujuan penelitian dan memenuhi segala kriteria persyaratan dalam pengambilan sampel(Sugiyono, 2017)meliputi:

1. Responden adalah mayoritas mahasiswa hingga pekerja di Kota Medan yang memiliki pendapatan mulai dari Rp 500.000 per bulan

2. Responden memiliki usia diantara 25 - 35 tahun

3. Responden menggunakan smartphone (selular untuk mengakses sosial media dan aplikasi $e$ commerce)

\section{HASIL DAN DISKUSI}

Pemanfaatan pengetahuan teknologi informasi yang harus dimiliki oleh para pelaku bisnis menjadi langkah awal untuk memajukan bisnis tersebut dan siap bersaing dengan produk yang sejenis di pasar E-commerce. Menurut (Sugiharto et al., 2019)e-commerce membawa manfaat dalam jual-beli secara online dengan perubahan kegiatan usaha era perdagangan ekonomi yang lama beralih ke era perdaganganekonomi yang baru: 
Tabel 1.1

Perubahan Kegiatan dari Model Lama ke Model Baru

Pada Era Perdagangan Ekonomi

\begin{tabular}{|l|l|l|l|}
\hline No & Jenis Kegiatan & Model Lama & Model Baru \\
\hline 1 & Pembelian \& Pemesanan & Harus datang ke Toko & Melihat di dalam website \\
\hline 2 & Pemasaran & Brosur dan spanduk & Digital Marketing \\
\hline 3 & Area pasar & Di area sekitar Toko & Internet global \\
\hline 4 & Pembayaran & Uang tunai & Non - tunai / cashless \\
\hline
\end{tabular}

Sumber data: (Sugiharto et al., 2019)

\section{Intensitas Pelanggan MembeliProduk}

UMKM Burger Sei Putih di Kota Medan telah berdiri sejak tanggal 30 November 1989. Pemilik usaha ini terdiri dari 3 (tiga) orang dengan komposisi kepemilikan penyertaan modal yang rata. Sampai saat ini kualitas, cita rasa dan varian masih sama seperti sekitar 30 tahun yang lalu, tidak ada perbedaan karena sang pemilik usaha tersebut tetap bertahan dan tidak ingin mengikuti trend bisnis kuliner saat ini. Mayoritas pembeli burger adalah mahasiswa sampai penduduk di sekitar Kota Medan. Menu yang disajikan yaitu, burger daging, burger ayam dan burger royal dan pisang bakar dengan harga yang terjangkau sampai dengan di tahun 2020 yaitu harga Rp 9.000,(sembilan ribu rupiah) untuk masing- masing jenis kecuali burger royal yaitu Rp 11.000,- (sebelas ribu rupiah).

Pada tahun 2017 hingga pertengahan tahun 2020 memasuki masa dunia digital yang dapat memasarkan bisnis secara online melalui e-commerceyang terdiri dari sosial media seperti Instagram, Blog dan marketplace khusus kuliner seperti Grab food, dan Go food membuat banyak usaha khususnya Burger Sei Putih semakin dikenal masyarakat luas. Harga yang terjangkau tentunya pasti menarik perhatian masyarakat untuk membeli sebuah produk terlebih memiliki nilai tambah jika masyarakat menuliskan ulasannya terhadap Burger Sei Putih di sosial media milik pelanggan. Tentu hal tersebut menjadi pemasaran secara ototmatis di dunia maya dan berdampak terhadap kenaikan penjualan. 


\section{Gambar 1.1}

\section{Data Intensitas Pelanggan Mengkonsumsi Burger}

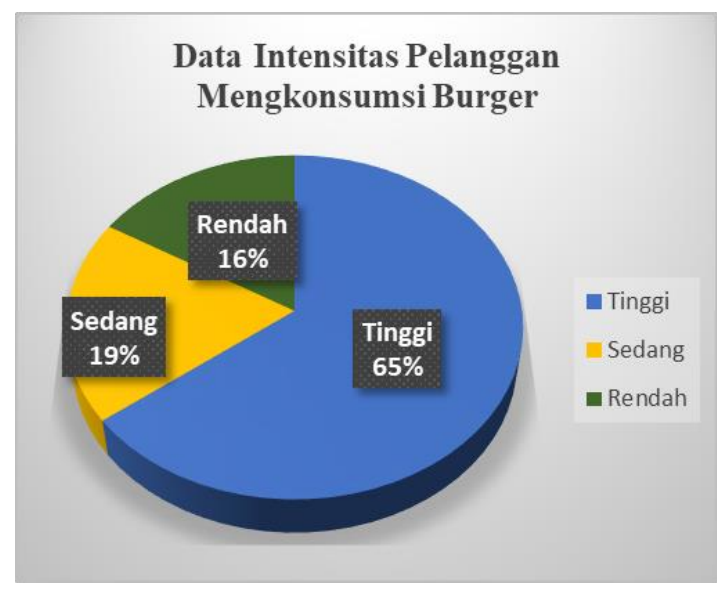

Sumber Data: Diolah Penulis, 2020

Hal ini diproksikan dengan tabulasi data yang diolah dari hasil survey yaitu kuesioner yang dibagikan kepada pelanggan yaitu pada gambar 1.1. diatas mengenai intensitas pelanggan mengkonsumsi Burger Sei Putih pada masa digital yaitu 2017- tahun berjalan 2020 terdapat sebanyak 65\% dalam seminggu 3 s/d 4 kali mengkonsumsi Burger, sedangkan sisanya $19 \%$ jarang membeli dan $16 \%$ memiliki intensitas yang rendah dalam membeli yaitu sebulan s/d dua bulan sekali. Sejalan dengan penelitian yang dilakukan oleh (Fauziyah \& Handayani, 2020) bahwa intensitas pemanfaatan $e$-commerce berpengaruh terhadap tingkat konsumsi siswa pada $e$ commerce shopee di SMANegeri 4 Malang.

\section{Transformasi Pemasaran Konvensional ke Digital}

Sejak berdirinya Burger Sei Putih hingga tahun 2016 pemasaran yang dilakukan oleh pemilik menggunakan pemasaran konvensional yaitu jenis pemasaran yang dilakukan secara langsung (bukan online) dengan metode-metode konvensional (menggunakan kebiasaan umum yang lazim digunakan). Pembeli mendatangi langsung calon penjual secara bertatap muka dan transaksi jual beli dilakukan dengan tunai seperti pada umumnya. Keuntungan pemasaran yang diperoleh burger ini adalah lokasi usaha yang strategis di tengah kota bertempat Jl. Sei Putih dan dekat dengan beberapa kampus seperti Universitas Sumatera Utara, Universitas Medan Area dan Universitas Darma Agung dan beberapa Sekolah Tinggi Swasta di sekitarnya. Banyak mahasiswa yang tertarik untuk membeli dengan harga yang terjangkau sesuai untuk ukuran uang saku 
mahasiswa. Menurut (Haryanto, 2020)pada tahun 2020 disebutkan bahwa ada 175,4 juta pengguna internet di Indonesia. Dibandingkan tahun sebelumnya, ada kenaikan 17\% atau 25 juta pengguna internet di negeri ini. Berdasarkan total populasi Indonesia yang berjumlah 272,1 juta jiwa, maka itu artinya 64\% setengah penduduk RI telah merasakan akses ke dunia maya.

Persentase pengguna internet berusia 16 hingga 64 tahun yang memiliki masing-masing jenis perangkat, di antaranya mobile phone (96\%), smartphone (94\%), non-smartphone mobile phone (21\%), laptop atau komputer desktop (66\%), tablet (23\%), konsol game (16\%), hingga virtual reality device $(5,1 \%)$. Artinya sekitar $94 \%$ masyarakat Indonesia memegang smartphone akan dapat melihat beragam macam dan jenis produk - produk yang dijual di dunia ini. Segmentasi pasar ini yang dibutuhkan oleh para pelaku usaha dalam hal ini UMKM Burger Sei Putih Kota Medan.

Hasil kuesioner yang dibagikan kepada responden tentang jenis- jenis media E-commerce yang digunakan sebagai informasi sekaligus media membeli produk Burger Sei Putihmenjelaskan pada gambar 1.2 bahwa Grab food adalah media atau tempat pemasaran onlinekhusus kuliner yang paling banyak digunakan oleh pelanggan untuk melihat informasi produkdan membeli produk burger yaitu sebesar 53\%, Go food sebesar 28\%, Instagram 15\% dan blog 4\%. Melalui informasi yang tersedia di sosial media dan market place dibawah ini yang menjadisalah satu jejaring tercepat dalam melakukan pemasaran bisnis.

\section{Gambar 1.2}

\section{Penggunaan Jenis MediaE-commerce}

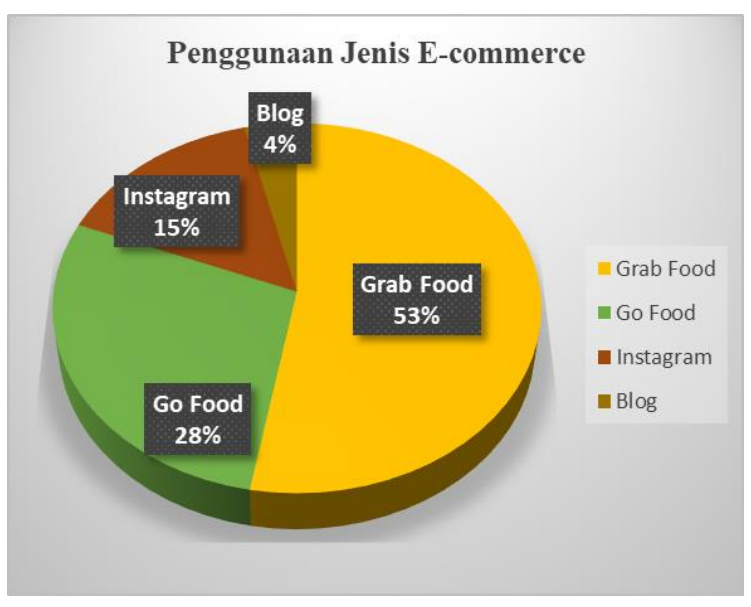

Sumber Data: Diolah Penulis, 2020 


\section{Manfaat $E$ - commerce Pada Burger Sei Putih}

Hasil wawancara kepada pemilik dan para karyawan Burger Sei Putih, terdapat 3 (tiga) aspek yang diperoleh Burger Sei Putih yang diperoleh dalam memasarkan produknya di $e$ commerce yang berdampak pada kenaikan penjualan dan keuntungan yaitu adanya memberikan kepuasan pelanggan sebesar $13 \%$, pengembangan bisnis sebesar $12 \%$ dan sarana promosi sebesar $75 \%$.

\section{Gambar 1.3}

\section{Manfaat E-commerce Pada Burger Sei Putih}

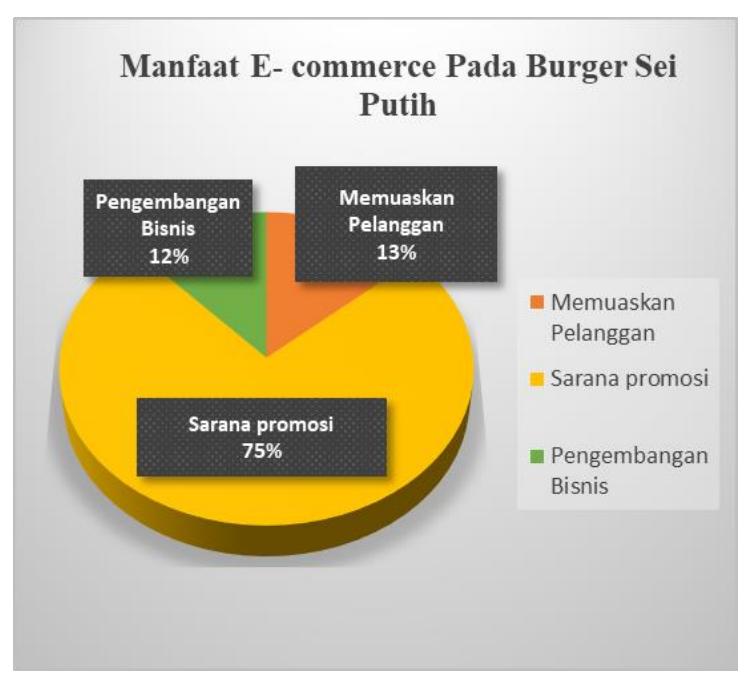

Sumber Data: Diolah Penulis, 2020

Pemilik usaha Burger Sei Putih mengatakan bahwa pada tahun 2019 hingga tahun berjalan 2020 Burger Sei Putih melakukan kemitraan atau menjadi merchantGrab food. Sarana promosi menjadi aspek penunjang peningkatan keuntungan bagi Burger Sei Putih ketika memilih pemasaran secara online. Manfaat masuknya Burger sebagai merchant di Grab foodmenjadikan burger sebagai restoran pilihan, layanan yang terpercaya dan diantar dengan cepat dan tepat waktu oleh kurirnya. Sistem pembayaran cashless (non - tunai) menjadi nilai tambah yang didapat oleh penjual dan pemilik usaha. Bagi penjual memberikan kepuasan pada pelanggan terletak pada tidak ada sistem antre menunggu pesanan dimasak, karena ketika pembeli memilih pesanan, dan kurir menuju lokasi para penjual sudah menerima pesanan lewat mesin EDC (Electronic Data Capture) sehingga ketika kurir sampai tujuan lokasi usaha, maka pesanan sudah siap untuk dibawa ke pelanggan. Sedangkan manfaat bagi pemilik adalah transaksi keuangan langsung masuk ke dalam rekening sang pemilik 
usaha, sehingga pemilik tidak perlu mengkhawatirkan adanya celah kecurangan yang dilakukan karyawan pekerja, hal ini yang menjadi acuan pemilik untuk bisa mengembangkan bisnis dengan terkendalinya transaksi keuangan yang berdampak pada kemampuan investasi asset.

\section{Kenaikan Penjualan Produk}

Observasi yang dilakukan oleh peneliti selama dua bulan dan wawancara kepada pemilikusaha menilai bahwa ada celah yang tidak baik yang dilakukan oleh pihak karyawan yang bekerja. Karena penjualan yang dilakukan masih $100 \%$ dengan menggunakan cash (tunai) pada saat pelanggan membeli, maka tidak $100 \%$ pula dapat diawasi dan dikendalikan oleh pemilik. Kepercayaan pemilik hanya berdasarkan pembukuan manual yang dicatat oleh karyawan setiap hari dan keuntungan yang didapat dilihat berdasarkan patokan persediaan telur dan daging. Telur yang dikeluarkan setiap hari 300 butir dan daging ayam serta daging sapi 300 buah. Pembukuan akan diperiksa oleh pemilik keesokan hari dan menyesuaikan dengan fisik kas yang ada.

Pada tahun 1989 sampai 2012 pemasaran masih menggunakan metode konvensional dengan pembayaran tunai. Tahun 2013 sampai 2016 muncul ulasan-ulasan di jejaring sosial seperti Instagram dan Blog yang membuat semakin banyak masyarakat tertarik datang membeli langsung Burger dan masih dengan pembayaran secara tunai. Memasuki tahun 2017 - 2019 muncul market place seperti Grab food dan Go food yaitu kurir dapat membelikan produk yang dipilih oleh pelanggan melalui aplikasi smartphonemilik pelanggan. Kemitraan bisnis ini telah memberikan keuntungan antara pihak penjual produk, Grab dan Driver (komisi kurir) dengan syarat memiliki standarisasi nominal penjualan kotor per bulan yang ditetapkan pihak Grab food.

\section{Tabel 1.2}

Perubahan metode transaksi penjualan Burger Sei Putih

\begin{tabular}{|l|l|l|l|}
\hline \multicolumn{1}{|c|}{ No } & \multicolumn{1}{|c|}{ Periode } & \multicolumn{1}{|c|}{ Keterangan } & \multicolumn{1}{|c|}{$\begin{array}{c}\text { Pembayaran Tunai } \\
\text { dan Non Tunai }\end{array}$} \\
\hline 1 & $1989-2012$ & $\begin{array}{l}\text { Mayoritas pembeli adalah secara langsung atau } \\
\text { transaksi bertatap muka antara penjual dan } \\
\text { pembeli }\end{array}$ & Tunai \\
\hline 2 & $2013-2016$ & $\begin{array}{l}\text { Instagram dan Blog menjadi salah satu media } E- \\
\text { commerce yang menginformasikan produk } \\
\text { Burger }\end{array}$ & Tunai \\
\hline 3 & $2017-2019$ & $\begin{array}{l}\text { Grab food dan Go food } \\
\text { Secara Langsung dan mitraGrab food melalui } \\
\text { OvO }\end{array}$ & Tunai dan Non Tunai \\
\hline
\end{tabular}

Sumber Data: Diolah Penulis, 2020 
Sampai saat ini burger Sei Putih masih tetap memiliki dua sumber transaksi penjualan yaitu manual (tunai) dengan transaksi secara langsung dan pembelian online (non tunai) dimana keuntungan langsung masuk ke rekening pemilik. Dengan adanya dua sumber transaksi penjualan maka pemilik setiap hari menyesuaikan struk atau resipesananyang keluar dari mesin EDC, jumlah uang yang masuk ke rekening serta persediaan barang. Keuntungan yang diperoleh antara transaksi cash (tunai) dengan non tunai adalah seimbang yaitu 50:50.

Kenaikan penjualan yang diperoleh Burger Sei Putih ketika memanfaatkan $E$ commerceadalah penjualan burger pada tahun 2013 - 2016 (sebelum memanfaatkan e-commerce) memiliki penjualan kotor rata- rata sebesar Rp 45.000.000 (empat puluh lima juta rupiah) / bulan. Tahun 2017 - tahun berjalan 2020 setelah memanfaatkan $e$-commerce dan melakukan mitra kerja sama dengan Grab Foodmaka penjualan kotor rata - rata mencapai Rp 118.252.718 (seratus delapan belas juta dua ratus lima puluh dua ribu tujuh ratus delapan belas rupiah) / bulan. Kenaikan penjualan kotor yaitu sebesar $163 \%$ dan kenaikan laba bersih yang diperoleh sebesar $134 \%$. Kenaikan yang signifikan ini selain karena adanya pemasaran secara online namun diperoleh juga karena produksi yang dijual dan harga yang ditetapkan sangat terjangkau dari tahun 1989 (sejak berdiri).

\section{Dampak Pemanfataan $E$ - commerce Dalam Peningkatan Penjualan Burger Sei Putih Kota} Medan

Timbulnya dampak positif yang diperoleh Burger Sei Putih pada saat memanfaatkan $e$ commerce pada produk usaha mereka adalah (1) kenaikan keuntungan penjualan, (2) memiliki sistem pengendalian internal yang lebih baik, (3) relasi untuk bermitra bertambah, (4) lebih dikenal masyarakat luas,(5) mendapat kelebihan dana untuk investasi, (6) kemudahan transaksi dan (7) hemat biaya promosi.

Dampak negatif yang diperoleh pelaku usahapada saat memanfaatkan $e$ - commerce pada produk usaha mereka adalah(1) kurir tidak mengetahui menu yang habis ketika pelanggan membuat pesanan dan bisa terjadi pembatalan pesanan dan merugikan kurir, (2) semakin dikenal luas oleh masyarakat berdampak kepada padatnya pengunjung namun tidak tersedianya lahan parkir yang luas (3) kendala jaringan yang menghambat mesin EDC bekerja menerima pesanandari pelanggan dan (4) adanya pesanan fiktif yang merugikan pelaku usaha dan driver (kurir).

Dampak positif yang diperoeh dari penelitian ini sejalan dengan penelitian yang dilakukan oleh (Suprapto, 2016) yaitu adanya kenaikan penjualan sebesar 17\% antara penjualan memakai aplikasi E-Commerce dengan sebelum memakai aplikasi E-Commerce. Selanjutnyapenelitian yang 
sejalan dari (Rakanita, 2019) menunjukkan bahwa pemanfaatan e-commerce akan dapatmeningkatkan pendapatan UMKM, produk yang dipasarkan akan lebih mudahdikenal oleh konsumen sehingga memudahkan dalam mendapatkan pelanggan, dapat menghemat biaya promosi danmeningkatkan kecepatan bertransaksi. Penelitian yang dilakukan oleh (Fauzi, 2020) memiliki hasil yang sama yaitu adanya nilai positif pemanfaatan e-commerce terhadap perilaku berwirausahamahasiswa PLS UNNES.

Berbeda dengan hasil penelitian dari (Wiyani \& Nugroho, 2013) dimana sumber daya manusianya kurang terampil dalam memanfaatkan teknologi untuk pemasaran produk,sehingga menghambat perluasan pemasaran. Dalam penelitian ini Burger Sei Putih memiliki mayoritas karyawan berusia 20-27 tahun tentunya mahir mengakses sosial media sehingga dengan cepat dan mudah memahami teknologi yang berhubungan dengan Grab Food tersebut. Kemampuan ini yang menjadi nilai tambah bagi usaha tersebut berjalan.

\section{KESIMPULAN}

1. Keuntungan yang dirasakan oleh pelaku usaha yaitu semakin tinggi intensitas masyarakat lokal kota Medan membeli Burger Sei Putih dengan adanya informasi produk tersebut yang dipasarkan secara online yaitu pada Instagram, Blog, Grab food dan Go food.

2. Manfaat E - commerce yaitu dengan bermitra pada Grab food bagi Burger Sei Putih adalah dapat memuaskan pelanggan yaitu pesanan diantar tepat waktu, sebagai sarana promosi produk lebih luas ke masyarakat dan pengembangan bisnis.

3. Dampak positif dari setelah pemanfaatan $E$ - commerce dalam peningkatan penjualan adalah memiliki kenaikan laba bersih $134 \%$, relasi mitra bertambah, dikenal masyarakat luas, sistem pengendalian internal dan manajemen keuangan semakin baik sehingga dapat melakukan investasi asset seperti emas dan tanah.

4. Dampak negatif dari pemanfaatan $E$ - commercedalam peningkatan penjualan adalahpembatalan pesanan dari pelanggan, tidak tersedianya lahan parkir yang luas, kendala jaringan pada mesin EDC dan peluang pesanan fiktif.

\section{REFERENSI}

Agusalim, F. (2020). Bab 2 Landasan teori. Retrieved from Anzdoc: https://adoc.tips/bab-2landasan-teori15f3b1811277c2319909f0292855644277139.html

Alfandia, N. S. (2019). Fasilitas E-Commerce Dan Pajak Hotel Pada Sektor Pariwisata. Media Bina Ilmiah, 14(3), 2161-2168. 
Dewinta, I. A. R., \& Setiawan, P. E. (2016). Pengaruh Ukuran Perusahaan, Umur Perusahaan, Profitabilitas, Leverage, Dan Pertumbuhan Penjualan Terhadap Tax Avoidance. E- Jurnal Akuntansi Universitas Udayana, 14(3), 1584-1613.

Fauzi, A. N. (2020). Pengaruh Pemanfaatan E-Commerce Terhadap Perilaku Berwirausaha Bagi Mahasiswa Pendidikan Luar Sekolah (Pls) Universitas Semarang (UNNES). https://lib.unnes.ac.id/35923/

Fauziyah, M. A., \& Handayani, S. (2020). Pengaruh Intensitas Pemanfaatan E-Commerce Dan Tingkat Literasi Ekonomi Terhadap Tingkat Konsumsi Siswa Di SMA Negeri 4 Malang 1, 2. Jurnal Pendidikan Ekonomi, 13(1), 76-83.

Fitriyadi, E. P. (2019). Inovasi E-Commerce Dan Starup Sebagai Tantangan Masyarakat Industri 4.0. Journal Teknologi Dan Informasi ESIT, XIV(03), 34-39.

Haryanto, A. T. (2020, Februari 20). Cyberlife. Retrieved from Detikinet: https://inet.detik.com/cyberlife/d-4907674/riset-ada-1752-juta-pengguna-internet-di-indonesia

Ngafifi, M. (2014). Kemajuan Teknologi Dan Pola Hidup Manusia Dalam Perspektif Sosial Budaya. Jurnal Pembangunan Pendidikan: Fondasi Dan Aplikasi, 2(1), 33-47. https://doi.org/10.21831/jppfa.v2i1.2616

Pradana, M. (2015a). Klasifikasi Bisnis E-Commerce Di Indonesia. Modus, 27(2), 163-174. https://doi.org/10.24002/modus.v27i2.554

Pradana, M. (2015b). Klasifikasi Jenis-Jenis Bisnis E-Commerce Di Indonesia. Jurnal Neo-Bis, $9(2), 32-40$.

Pradiani, T. (2018). Pengaruh Sistem Pemasaran Digital Marketing Terhadap Peningkatan Volume Penjualan Hasil Industri Rumahan. Jurnal Ilmiah Bisnis Dan Ekonomi Asia, 11(2), 46-53. https://doi.org/10.32812/jibeka.v11i2.45

Rakanita, A. M. (2019). Pemanfaatan E-Commerce Dalam Meningkatkan Daya Saing Umkm Di Desa Karangsari Kecamatan Karangtengah Kabupaten Demak. Jurnal Ekbis, XX(2), 12801289.

Setyanto, A. R., Samodra, B. R., \& Pratama, Y. P. (2015). Kajian Strategi Pemberdayaan UMKM Dalam Menghadapi Perdagangan Bebas Kawasan ASEAN (Studi Kasus Kampung Batik Laweyan). Etikonomi, 14(2), 205-220. https://doi.org/10.15408/etk.v14i2.2271

Siska Maya. (2016). Strategi Peningkatan Penjualan Usaha Kecil Menegah Melalui E- Commerce Studi Kasus : Mitra UKM Perusahaan X. JABE; Journal of Applied Business and Economics, 2(3), 271-279.

Sugiharto, Umar, A., Sasongko, A. H., \& Aguzman, G. (2019). Pemanfaatan Pembayaran Online Bagi E-Commerce Usaha Kecil Dan Menengah. Buletin Bisnis \& Manajemen, 05(1), 2019.

Sugiyono. (2017). Metode Penelitian Bisnis (Pendekatan Kuantitatif, Kualitatif, Kombinasi dan R\&D). In Metodelogi Penelitian.

Suprapto, H. A. (2016). Pengaruh Penetapan Harga Dan E-Commerce Terhadap Tingkat Penjualan Pada Usaha Jack Donut Di Curug Tanah Baru Depok. JABE (Journal of Applied Business and Economic), 2(4), 345-354. https://doi.org/10.30998/JABE.V2I4.1527 
Talenta, I. (2020). Retrieved from Pengertian Penjualan, Tujuan dan Bentuknya Dalam Perusahaan: https://www.talenta.co/blog/insighttalenta/penjualan/\#: :text=Menurut\%20William\%20G. $\% 20$ Nickels\%2C\%20penjualan,dan\%20menguntungkan\%20kedua\%20belah\%20pihak.

Wiyani, F., \& Nugroho, A. P. (2013). Peningkatan Daya Saing Bisnis "Batik Kahuripan" Melalui Sistem Penjualan Berbasis E-Commerce. Seminar Riset Unggulan Nasional Informatika Dan Komputer FTI UNSA, 2(1), 25-32. 